\title{
AN EVALUATION OF GUIDED READING IN THREE PRIMARY SCHOOLS IN THE WESTERN CAPE
}

\author{
A Kruizinga \& R Nathanson ${ }^{1}$ \\ University of Stellenbosch
}

Given that the South African government intends to improve its literacy rates by implementing Guided Reading in the primary schools, teachers are challenged to give good quality Guided Reading instruction. The study which this article draws on evaluates how teachers understand and implement Guided Reading in Grade 1 and 2 at three public schools in the Western Cape. Data were drawn from observations of teachers using Fountas \& Pinnell's Guided Reading instruction and a Guided Reading Self-Assessment Inventory. Analyses of the abovementioned quantitative and qualitative research data indicate that South African teachers have a superficial understanding of Guided Reading. The study suggests that South African teachers struggle to implement Guided Reading in the classroom, because they do not create Guided Reading groups based on ongoing assessment and the teachers do not have access to levelled Guided Reading books. Furthermore, the new policy requirements for Guided Reading appear to fail to offer teachers a sufficient explanation of Guided Reading. I argue that, without addressing these basic requirements, it is unlikely that Guided Reading will be implemented with any success in the South African classrooms.

\section{INTRODUCTION}

Learners' achievements are often used as indicators for the efficiency of an educational system. A number of national and international studies have shown that South African learners' achievements are poor for both mathematics and reading. With regard to reading, the Southern and Eastern Africa Consortium for Monitoring Educational Quality (SACMEQ II, 2000) found that the overall reading level of Grade 6 learners in South Africa stood at Level 3 (basic reading). The Progress in International Reading Literacy Study (PIRLS, 2006) showed that South African Grade 4 and 5 learners scored below the international mean of 500 points at 302 points. Likewise, the South African Department of Education Systematic Evaluation (2007) showed that the Grade 3 achievement score for literacy was 36\%. The Western Cape Education Department Learner Assessment Study (2007) showed that the pass rate for Grade 6 learners was 44,8\%. Fleisch (2008) and Dixon and Peake (2008) point out that the results of literacy tests indicate that large numbers of South African learners cannot understand what they are reading.

\footnotetext{
${ }^{1}$ This article is based on Kruizinga's dissertation, supervised by R. Nathanson and presented for the Degree of Master of Education at Stellenbosch University.
} 
As part of the governmental response to the high levels of illiteracy in South African schools, the Department of Education implemented a balanced language programme, as set out in the National Reading Strategy (2008:4-21) and the Foundation for Learning Campaign (Government Gazette, No. 30880, 2008:4-11). Guided Reading is regarded as one of the key components of a balanced language programme (Hornsby, 2000; Fountas \& Pinnell, 1996). During Guided Reading the teacher works with a small group of children who are able to read similar levels of text with support (Hornsby, 2000). The teacher helps each reader develop strategies for comprehending increasingly challenging texts (Pinnell \& Fountas, 2007). Thus, Guided Reading builds the process of individual reading and it teaches children how the reading process works (McPherson, 2007:1; Kouri, Riley \& Selle, 2006: 236; Schwarts, 2005: 442). Because Guided Reading teaches children how to construct meaning independently from text under a teacher's supportive guidance, it is particularly appropriate for children who are in the early years of literacy development and for the lowest performing children (Iaquinta, 2006:413 (Fountas \& Pinnell, 1996:1-2; Hornsby, 2000:30-34).

The theoretical underpinnings of Guided Reading are concerned with the teaching of reading for meaning. A social constructivist learning theory (Vygotsky, 1962:133), a transaction reading model (Rosenblatt, 1963:4) and a balanced instructional approach (Hornsby, 2000:1415; Fountas \& Pinnell, 1996:22 - 24) emphasise that readers construct the meaning of the text through cognitive and social processes. Furthermore, Guided Reading draws on a whole language philosophy (Weaver, 2002:24). This means that instruction is based on whole texts that allow readers to coordinate a range of strategies (e.g. using prior knowledge, predicting and cross-checking semantic, syntactic and visual cues in text) to reduce uncertainty about unknown words and their meanings. Since 'most written language occurs as continuous text', the reader's task is to learn to 'problem-solve messages in continuous text' (Clay, 2005:2). Therefore, advocates of whole language approaches argue that teaching children words or letters in isolation before allowing them to read texts is not the most appropriate learning context for developing effective comprehension strategies (Clay, 2005:2). Based on the belief that humans construct their own knowledge, whole language approaches do not try to control which sources of information in a text the child should learn first (Clay, 1991:17). While this view gives the teacher flexibility to meet individual differences, it also means that teachers have an important role in selecting texts for Guided Reading instruction that are closely matched to a particular group's reading needs (Hornsby, 2000:48).

As mentioned, Guided Reading is seen by the South African government as a tool to improve literacy rates in schools (Bloch, 2009:128; READ, 2009:5). This begs the question whether and how schools are implementing Guided Reading? The current study sought to evaluate how teachers understand and implement Guided Reading in Grade 1 and 2 at three public primary schools in the Western Cape. The study focused on Guided Reading in the early stages of children's reading development, because in this phase learners build foundational cognitive networks for future reading (Clay, 1993:15). Iaquinta (2006: 413) explains that 'the early years are the focus for the prevention of reading difficulties and research conducted over the past two decades has produced extensive results demonstrating that children who get off to a poor start in reading rarely catch up'. Bell (2009:8) and Fleisch (2008:30) are therefore of the opinion that, unless the proper groundwork has been laid in South African primary schools, children will continue to struggle in education. 


\section{RESEARCH DESIGN}

In order to evaluate how teachers understand and implement Guided Reading, I conducted implementation evaluation research in Grade 1 and 2 at three primary schools (Mouton, 2001: 158-159; McMillan \& Schumacher, 2001:537). McMillan and Schumacher (2001:537) explain that this type of research 'assesses the extent to which a program is developed or implemented as planned, and it identifies any defects in the program'. Therefore, implementation evaluation methodology underpins this study, because it aims to answer the question whether a Guided Reading programme has been well conceptualised and implemented (Airasian, Gay \& Mills, 2006:7; Mouton: 2001:158-159). In addition, by identifying weaknesses in the implementation of Guided Reading in selected schools, the study aims to inform educational policy and practice (Purcell, 2000:3; Demetriou, Charalambous \& Kyriakides, 2006:2-3).

A triangulation mixed-methods approach in which 'quantitative data and qualitative data are equally weighted and are collected concurrently throughout the same study' was also used (Airasian, Gay \& Mills, 2006:491). Triangulation integrates data-gathering methods throughout the research process, which contributes simultaneously to the findings (Opie, 2004:72; Slavin, 2007:133-139). A mixed-methods approach has the advantages of providing observational notes to add meaning to numbers, but also uses numbers to add precision to the observational description (Connelly, 2009:32). These features made a triangulation mixedmethods approach best suited to answer my research question.

Fountas and Pinnell's (1996:283-285) Guided Reading Self-Assessment inventory was used to obtain quantitative data. This specific inventory was selected because it is a reflection tool especially developed by researchers at Ohio State University who are leaders in the field of Guided Reading. The Guided Reading inventory requires teachers to question their current practices by marking descriptors of their teaching behaviours on a scale of 1 to 4 (Fountas \& Pinnell, 1996:283-285; Lyons \& Pinnell, 2001). Teaching behaviours are categorised under ten headings, namely: materials, classroom management, grouping, lesson management, text selection, introduction, teaching decisions, children's talk, engagement and pace (Fountas \& Pinnell, 1996:283-285). For example, under the category 'text selection' the teachers can choose a descriptor on a continuum of 1 to 4 . Score 1 indicates that the teacher is 'just beginning to understand how to select text that is right for the group', whereas, at the opposite end, score 4 indicates that a teacher can 'select texts that are at an appropriate level for most of the group and that support their development of strategies' (See Addendum A for an example of the descriptors under the category 'text selection'). The Guided Reading SelfAssessment inventory also includes an open-ended section, which gives teachers opportunity to add any comments (Lyons \& Pinnell, 2001).

Qualitative data were obtained through non-participant observation (Slavin, 2007:130; Airasian, Gay \& Mills, 2006: 414). First, I conducted classroom observations in grade 1 and 2 for a period of one school week at every participating school. During this time I wrote observational field notes, which described how teachers implemented Guided Reading instruction in their classrooms. Second, each teacher completed a Guided Reading SelfAssessment inventory, which provided me with information on teachers' self-reflections of their understanding and implementation of Guided Reading in their classrooms (Fountas \& Pinnell, 1996:189-194; Leedy, 1993:195). Third, I completed a Guided Reading SelfAssessment inventory for each teacher, which codified my reflections on the teachers' understanding and implementation of Guided Reading in the classrooms and gave me the 
opportunity to cross-check data. Then, I compared the teachers' outcomes from the Guided Reading Self-Assessment inventory with the assessment outcomes of my observations and inventories to see if the teachers' self-reflection and understanding of Guided Reading agreed with my observations. Next, I used the ten previously discussed categories of the Guided Reading Self-Assessment inventory to codify patterns, such as text selection and lesson management, in the Guided Reading instructions at all three schools.

In addition, I reviewed literature with the aim of describing theories underpinning Guided Reading and studied the match between theory, policy and practice. My literature review formed the conceptual base for analysing the data of the inventory. The trustworthiness of the study was maintained through the triangulation mixed-method approach of comparing and crosschecking of research data, and through clarification of theoretical underpinnings of the research and of Guided Reading instruction (Connelly, 2009:32; Rolfe, 2006:305; Golafshani, 2003:601; Moss, 2004:371).

\section{RESULTS}

By using implementation evaluation methodology, this small-scale study examined how six South African primary teachers understood and implemented Guided Reading in their classrooms. All six teachers at the three schools participating in the study stated that they followed the guidelines for Guided Reading as set out in the National Reading Strategy (2008) and the Foundation for Learning Campaign (2008).

\section{OVERVIEW OF OUTCOMES IN THE GUIDED READING SELF-ASSESSMENT INVENTORY}

The section on the research design explained how the Guided Reading Self-Assessment inventory was used in this research to obtained quantitative data. The main findings derived from the inventory are summarised in Table 1.

TABLE 1: Overview of scores in the Guided Reading Self-Assessment inventory

\begin{tabular}{|c|c|c|c|}
\hline & & $\begin{array}{l}\text { Teacher's score } \\
\text { (maximum score for } \\
\text { each grade is 40) }\end{array}$ & $\begin{array}{l}\text { Researcher's score } \\
\text { (maximum score for } \\
\text { each grade is } 40 \text { ) }\end{array}$ \\
\hline \multirow[t]{3}{*}{ School A } & Grade 1 & 25 & 18 \\
\hline & Grade 2 & 24 & 17 \\
\hline & Total & 49 & 35 \\
\hline \multirow[t]{3}{*}{ School B } & Grade 1 & 29 & 12 \\
\hline & Grade 2 & 28 & 13 \\
\hline & Total & 57 & 25 \\
\hline \multirow[t]{3}{*}{ School C } & Grade 1 & 35 & 13 \\
\hline & Grade 2 & 38 & 13 \\
\hline & Total & 73 & 26 \\
\hline
\end{tabular}


Table 1 shows differences between the teachers' scores and my scores. In all cases my scores were lower than the teachers' scores, especially in the middle-class school, C. The latter finding is surprising in that the general perception is that economically advantaged schools would have well-educated teachers with much insight into their own practices. However, this does not seem to be the case. It is possible that these teachers, because they worked with middle-class children, were not challenged to change their current practices because their students performed well in their current reading programme. This brings to mind Witte's (1996:164) study, which indicated that, if you control for students' background variables, teachers from schools serving middle to high class students add very little value to actual learning compared to schools that serve low socio-economic status communities. Another explanation for the differences between teachers' scores and my scores could be that the teachers were not familiar with the theoretical base underpinning Guiding Reading, and therefore were not as critical of their own practices as they could have been.

Table 1 illustrates that the teachers of school A gave themselves the lowest score, but I gave them the highest score on the basis of my observations that teachers in this school followed the structure of a Guided Reading lesson, namely, introduction, independent reading, revisiting the text and responding to the text, (Hornsby, 2000:100-105; Davidson, 1991:2829). At the time of this study, the teachers of school A were receiving training in Guided Reading from the Trust Organization READ, as part of the Western Cape Education Department's drive for improving literacy. This could mean that these teachers were more critically aware of their own practices.

Both the quantitative and qualitative data suggest that the Grade 1 and 2 teachers of school A seemed to be developing an understanding of the structure of Guided Reading as outlined by Hornsby (2000:100-105) and Davidson (1991:28-29). However, although the teachers in school A implemented the form of Guided Reading, they appeared to have great difficulty in implementing the intent of Guided Reading, namely, supporting children to become independent readers through building reading strategies on unknown text.

The teachers of schools B and C, on the other hand, did not follow the steps from Guided Reading, which revealed a lack of understanding of Guided Reading instruction. The teachers of schools B and C used their Guided Reading time to listen to children reading aloud, instead of focusing on the development of reading strategies, which indicates that these teachers were maintaining a behaviourist and transmission view of reading. Although these observations show that there are certain overlaps between teachers' instructional practices, such as reading aloud, instructional practices also differed. For example, some teachers gave Guided Reading instruction to the whole class; others first read the book to a small group of children.

There was little to no evidence at any of the three schools of children who were interactively engaged in discussing the meaning of books during Guided Reading. All six teachers gave the impression that they found it difficult to support children during Guided Reading; they frequently read the text for the children when the children struggled to decode the text. This type of teaching reading does not stimulate children to use reading strategies to problem-solve unfamiliar text so that they can become independent readers (Clay \& Cazden, 1992:131; Cooper, 2000:426; Weaver, 2002:329).

The outcomes of the Guided Reading Self-Assessment inventory also indicated that the teachers participating in this study did not have enough Guided Reading books to work with. 
Most of the texts they used in Guided Reading lessons were familiar to the children, because the teachers had already read the text for them during Shared Reading. Teachers did not select text based on each child's reading needs; instead every child read the same Guided Reading book (Peterson, 2001:122-124; Paratore \& McCormack, 2005:55; Clay, 1993:23). To complicate matters, none of the participating schools had levelled sets of books on a continuum of easy to more difficult to support children's developing processing systems. This makes it challenging for the teachers to select appropriate texts and implement Guided Reading as described in the theory base.

Additionally, the study revealed that the teachers at the three schools did not create Guided Reading groups according to recommendations in the theory base. For example, Guided Reading groups in all three schools were based on where the children were sitting in the class. Thus, the children were sitting in groups, but were not grouped according to similar reading behaviours, as outlined in the theory base. Likewise, the theory base suggests that teachers should use assessments, such as running records, to inform them when children should be promoted to new books or moved to different Guided Reading groups (Clay, 1993:20-42; Flood, Lapp, Moore \& Nichols, 2005:116). Dynamic grouping procedures are important to ensure that children do not stay in the same group all year (Fountas \& Pinnell, 1996:97-106; Iaquinta, 2006:414).

Giving Guided Reading lessons to the whole class at the same time or paying attention to different groups during a guided reading lesson was a common practice in the participating schools. This contradicts the research-based principles of Guided Reading instruction, which is a teaching context in which children in small groups learn how to read (Tracy \& Morrow, 2006:141; Hornsby, 2000:34). Teachers are supposed to spend quality time working with one group at a time during Guided Reading and not have their time divided between different groups or the whole class.

To summarise, the participating teachers seemed to have a very superficial understanding of Guided Reading, which indicates that reforms were not being implemented correctly in the classrooms in this study. Development of teachers in understanding Guided Reading is a process that needs ongoing theoretical and practical support. In addition, the teacher's implementation of Guided Reading in the classroom requires the right materials, e.g. levelled Guided Reading books and proper assessments.

\section{CONCLUSION}

As mentioned, the research question of the study was: How do teachers understand and implement Guided Reading in Grade 1 and 2 at three public primary schools in the Western Cape? I acknowledge that the study is a small-scale study and, as such, it is hard to draw conclusions that can be generalised. However, this study does represent Guided Reading practice in six South African classrooms and underscores the trend that reforms are poorly implemented in most South African schools, partly because of the lack of resources (Bloch, 2009; Fleisch, 2008; Christie, 2008; Conley, Du Plessis \& Du Plessis, 2007; Jansen, 2005).

The study concludes that the teachers participating in the study have a very superficial understanding of Guided Reading, based on their behaviouristic interpretation of the national literacy policy, rather than on the research and theoretical base. This raises the question why literacy reforms, such as Guided Reading, seem to be difficult to implement in the classroom. By reflecting on the route from theory and policy to practice, it is possible to identify some 
stumbling blocks to reform. First, the new policy requirements for Guided Reading as outlined in the National Reading Strategy (2008) and Foundation for Learning Campaign (2008) appear to fail to offer teachers a sufficient explanation of Guided Reading and sometimes even contradict the theoretical base. Unclear governmental documents are likely to leave space for teachers' own interpretations of Guided Reading, which works against reform. Second, teachers' interpretations of policy are formed by their teaching history, for instance their transmission view on reading, their school context, their own education. The cumulative effect of all these varied misinterpretations is individualistic Guided Reading instruction, as illustrated by my classroom observations. Without a clear explanation of Guided Reading and practical support, it is likely that South African teachers will continue following their traditional approach to reading and individualistic way of interpreting and implementing Guided Reading, because they do not fully understand the concept and value of Guided Reading.

A third stumbling block to reform is the lack of resources, such as levelled Guided Reading books and assessment. The participating schools did not have levelled books in a coherent system that allowed accurate matching of text and child. This meant that the schools did not have a consistent national standard to compare reading levels across schools. In the light of these arguments, it is evident that the teachers in the three schools encountered serious practical problems in trying to implement Guided Reading in their classrooms. In the absence of teacher education and clear explanations of how to create assessment-based Guided Reading groups and without levelled Guided Reading books, teachers will not have the opportunity to implement Guided Reading correctly in their classrooms.

To conclude, the disparity between theory, policy and practice resulted in individualistic, disjointed implementation of Guided Reading in six South African classrooms. One is tempted to speculate that the problem is more wide-spread, because policy documents were distributed to all schools in South Africa and it is well known that many schools are poorly resourced (Bloch, 2009; Nathanson, 2008). This is a serious concern, because Guided Reading comprises the heart of a balanced, comprehensive, language programme and it therefore has the most potential of improving literacy rates in South Africa, especially for the children performing at the lowest level (Iaquinta, 2006:413; Fountas \& Pinnell, 1996: 1-2; Hornsby, 2000:30-34).

\section{REFERENCES}

AIRASIAN, P, LR GAY \& GE MILLS. 2006. Educational research: Competencies for analysis and applications. New Jersey: Pearson Prentice Hall.

BECK, CT \& DF POLIT. 2004. Nursing research: Principles and methods. Philadelphia: Lippincott Williams \& Wilkens.

BELL, T. 2009. We can't tax books and build a nation of readers. Sunday Times (Review), 19 July: 8.

BLOCH, G. 2009. The toxic mix: What's wrong with South Africa's schools and how to fix it. Cape Town: NB Publishers Tafelberg.

CHRISTIE, P. 2008. Opening the doors of learning. Johannesburg: Heinemann.

CLAY, M. 1991. Becoming literate: The construction of inner control. Auckland: Heinemann. 
CLAY, M. 1993. An observation survey of early literacy achievement. Auckland: Heinemann.

CLAY, M. 2005. Literacy lessons designed for individuals. Part one. Auckland: Heinemann.

CLAY, MM \& C CAZDEN. 1992. A Vygotskian interpretation of Reading Recovery. Whole language plus: Essays on literacy in the United States \& New Zealand. Columbia: Teachers College Press. 114-135.

CONLEY, L, E DU PLESSIS \& P DU PLESSIS. 2007. Teaching and learning in South African schools. Pretoria: Van Schaik.

CONNELLY, LM. 2009. Mixed methods studies. Medsurg Nursing, 18(1):31-32.

COOPER, JD. 2000. Literacy: Helping children construct meaning. Boston: Houghton Mifflin.

DAVIDSON, A. 1991. Literacy links: Teachers' resource. Stages 1 \& 2. Auckland:

Shortland.

DEMETRIOU, D, C CHARALAMBOUS \& L KYRIAKIDES. 2006. Generating criteria for evaluating teachers through effectiveness research. Educational Research, 48(1):1-20.

DEPARTMENT OF EDUCATION. 2007. Systematic Evaluation Foundation Phase. Pretoria: Leaflet [Online]. Available: http://www.education.gov.za/dynamic/dynamic.aspx?pageid=326\&dirid=56 [2009, 15 October].

DEPARTMENT OF EDUCATION. 2008. National Reading Strategy. Pretoria: Government Printers.

DEPARTMENT OF EDUCATION. 2008. Foundation for Learning Campaign 2008 - 2011. Government Gazette, No. 30880, 14 March 2008. Pretoria: Government Printers.

DIXON, K \& K PEAKE. 2008. Straight for English: Using school language policy to resist multilingualism. English Teaching: Practice and Critique, 7(1):73-90.

FLEISCH, B. 2008. Primary Education in crisis: Why South African schoolchildren underachieve in reading and mathematics. Cape Town: Juta.

FLOOD, J, D LAPP, K MOORE \& M NICHOLS. 2005. Teaching literacy in first grade. New York: Guilford Press.

FOUNTAS, IC \& GS PINNELL. 1996. Guided reading: Good first teaching for all children. Portsmouth: Heinemann.

GOLAFSHANI, N. 2003. Understanding reliability and validity in qualitative research. The Qualitative Report, 8(4):597-607.

HORNSBY, D. 2000. A closer look at guided reading. Armadale Vic: Eleanor Curtain.

IAQUINTA, A. 2006. Guided Reading: A research-based response to the challenges of early reading instruction. Early Childhood Education Journal, 33(6):413-418.

JANSEN, J. 2005. Educationally essential: Teachers, textbooks and time. Conflict and Governance: Transformation Audit. Cape Town: Institute for Justice and Reconciliation. 
KOURI, TA, SA RILEY\& CA SELLE. 2006. Comparison of meaning and graphophonics feedback strategies for guided reading instructions of children with language delays. American Journal of Speech-Language Pathology, 15(3):326-246.

LEEDY, PD. 1993. Practical research: Planning and design. New York: Macmillan.

LYONS, C. \& PINNELL, G.S. 2001. System for change in literacy education: A Guide to Professional Development. Portmouth: Heinemann.

MCMILLAN, JH \& S SCHUMACHER. 2001. Research in education: A conceptual introduction. New York: Addison Wesley Longman.

MCPHERSON, K. 2007. Teacher-librarians as reading guides. Reading Teacher, 35(2):70-73.

MOSS, G. 2004. Provision of trustworthiness in critical narrative research: Bridging intersubjectivity and fidelity. The Qualitative Report, 9(2):359-374.

MOUTON, J. 2001. How to succeed in your Master's \& Doctoral Studies: A South African Guide and Resource book. Pretoria: Van Schaik.

NATHANSON, R. 2008. A school-based, balanced approach to early reading instruction for English additional language learners in grades one to four. Unpublished Doctoral dissertation. Stellenbosch University.

OPIE, C. 2004. Doing educational research: A guide to first-time researchers. London: Sage.

PARATORE, JR \& MCCORMACK, RL. 2005. Teaching literacy in second grade. New York: Guilford Press.

PETERSON, B. 2001. Literary pathways: Selecting books to support new readers. Westport: Heinemann.

PINNELL, G \& I FOUNTAS. 2007. The continuum of literacy learning, grades $K-8$. Portsmouth NH: Heinemann.

PROGRESS IN INTERNATIONAL LITERACY STUDY. 2006. PIRLS 2006 International report [Online]. Available: www.pirls.bc.edu/pirls2006/intl_rpt.html [2007, 30 August].

PURCELL-GATES, V. 2000. The role of qualitative and ethnographic research in educational policy. International Reading Association Reading Online, 4(1):1-6.

READ EDUCATIONAL TRUST. 2009. A balanced language programme and the foundation for learning campaign, 2009:3-32.

ROLFE, G. 2006. Validity, trustworthiness and rigour: Quality and the idea of qualitative research. Journal of Advanced Nursing, 53(3):304-310.

ROSENBLATT, LM. 1963. Research development seminar in the teaching of English. New York: New York University Press.

SACMEQ II. 2000. Harare: SACMEQ [Online]. Available: http://sacmeq.org/educationsouth-africa.htm\#reports [2009, 15 October].

SCHWARTS, RM. 2005. Decisions, decisions: Responding to primary students during guided reading. Reading Teacher, 58(5):436-443.

SLAVIN, RE. 2007. Educational Research: In an age of accountability. New York: Pearson Education.

TRACY, DH \& LM MORROW. 2006. Lenses on reading: An introduction to theories and models. New York: Guilford Press. 
VYGOTSKY, L. 1962. Thought and language. Cambridge: Massachusetts Institute of Technology.

WEAVER, C. 2002. Reading process \& practice. Portsmouth: Heinemann.

WESTERN CAPE EDUCATION DEPARTMENT. 2007. Learner Assessment Study Intermediate Phase. Cape Town: WCED. [Online]. Available: http://wced.wcape.gov.za/comms/press/2008/20_litnumgr6.html [2009, 15 October].

WITTE, J. 1991. School choice and student performance, in Ladd, H. (Ed), Holding schools accountable: Performance-based reform in education. Washington, D.C.: The Brookings Institution.

\section{BIOGRAPHICAL NOTE}

Renee Nathanson is a lecturer in the Department of Curriculum studies at Stellenbosch University. Her research interests include reading comprehension, early literacy intervention and professional development for literacy teachers. Alida Kruizinga completed the Master of Education studies in development through literacy: An evaluation of Guided Reading in three primary schools in the Western Cape in 2010. E-mail address: rrn@sun.ac.za 